\title{
Popular Demobilization, Agribusiness Mobilization, and the Agrarian Boom in Post- Neoliberal Argentina
}

\author{
Pablo Lapegna \\ University of Georgia \\ plapegna@uga.edu
}

\begin{abstract}
Based on ethnographic research, archival data, and a catalog of protest events, this article analyzes the relationship between popular social movements, business mobilization, and institutional politics in Argentina during the post-neoliberal phase, which arguably began circa 2003. How did waves of popular mobilization in the 1990s shape business mobilization in the 2000s? How did contentious politics influence institutional politics in the post-neoliberal period? What are the changes and continuities of the agrarian boom that cut across the neoliberal and post-neoliberal periods? While I zoom in on Argentina, the article goes beyond this case by contributing to three discussions. First, rather than limiting the analysis to the customary focus on the mobilization of subordinated actors, it examines the demobilization of popular social movements, the mobilization of business sectors, and the connections between the two. Second, it shows the ways in which the state can simultaneously challenge neoliberal principles while also favoring the global corporations that dominate the contemporary neoliberal food regime. Finally, the case of Argentina sheds light on the political economy of the "Left turn" in Latin America, particularly the negative socio-environmental impacts of commodity booms. The article concludes that researchers need to pay closer attention to the connections between contentious and institutional politics, and to the protean possibilities of neoliberalism to inspire collective actions.
\end{abstract}

Keywords: Demobilization, Business mobilization, GM soybeans, neoliberalism, Argentina

In the last decade and a half, South America has experienced a series of political and social changes. Several governments in the region - including Venezuela, Argentina, Brazil, Uruguay, Paraguay, Bolivia, and Ecuador-have challenged many of the neoliberal policies initially implemented in the $1970 \mathrm{~s}$ and deepened in the $1990 \mathrm{~s}$, all while building strong alliances with popular social movements. This historical conjuncture has been labeled a "Left turn" (Cameron and Hershberg 2010; Levitsky and Roberts 2011), and different interpretations abound. Some emphasize its "populist" tendencies, questioning the excessive power of the executive branch and the lack of checks and balances (e.g. Weyland 2010), while others admonish governments for succumbing to reformism (e.g. Petras and Veltmeyer 2005; Webber 2011). Regardless of the 
labels, recent changes in South America indicate the role that state and social movements play in bringing about social change, posing a challenge to neoliberal globalization, and opening spaces for alternative futures (e.g. Smith and Wiest 2012).

In this article, I analyze the relationship between popular social movements, the state, and agribusiness in Argentina to bridge the literatures on critical agrarian studies, social movements, and "post-neoliberalism" in Latin America. In doing so, I pay particular attention to changes and continuities in contentious politics and the political economy of the agrarian boom in Argentina to illuminate empirical and theoretical issues concerning Latin America and the contemporary global food regime.

Argentina shares three features with its South American counterparts. First, social movements emerged in reaction to processes of neoliberalization, predating and promoting the anti-neoliberal agenda that was later implemented by the national government (Silva 2009). Second, similar to the cases of Bolivia and Venezuela, the Argentine government had to face the disruptive mobilization of business actors and elites that opposed a post-neoliberal agenda and de-stabilized the government (Domínguez 2011; Eaton 2007). Third, revenues yielded by agribusiness benefitted the state via export taxes, but the government largely ignored the environmental and social consequences of agricultural expansion (Binimelis, Pengue and Monterroso 2009; Leguizamón 2014), a situation comparable to the effects of the "commodity booms" in Bolivia, Brazil, Ecuador, and Paraguay (Altieri and Pengue 2006; Bebbington 2012; Haarstad 2012). Focusing on Argentina, my goal is to address three questions. How did waves of popular mobilization in the 1990 s shape business mobilization in the 2000s? How did contentious politics influence institutional politics in the post-neoliberal period? What are the changes and continuities of the South American "commodity boom" that cut across the neoliberal and post-neoliberal periods?

The article is based on primary data from interviews and participant observation and a database of protests based on newspaper reports. I did fieldwork for more than twelve months between 2003 and 2013, conducting forty-five semi-structured interviews in northeast Argentina and in Buenos Aires. The database of protests is based on the national newspaper Clarin, from which I collected records of 919 protests events for the 2003-2006 period, using a sampling method of revising Tuesday and Friday editions, and classifying each event by actors, actions, location, demands, and targets.

In what follows, I first elaborate my arguments on social movements and global agro-food systems in the post-neoliberal context, and then delve into the Argentine case to examine the ways in which popular mobilization, the state, and agribusiness mobilization shape each other and the country's political economy. In the conclusion, I draw the connections between the Argentine case and trends in Latin America more broadly, suggesting lines for future research.

\section{Food Regimes and Mobilization}

Critical agrarian scholars have been greatly influenced by the "food regime" perspective, which highlights the role of agriculture and food in the expansion of global capitalism (Friedmann and McMichael 1989). Historically, the transitions between global food regimes responded to changes in world capitalism and mobilization "from below" (Friedmann 2005), as the global food regime dominated by British Empire (ca. 1870-1930s) was followed by a regime that developed under U.S. hegemony (ca. 1950s-1970s). The contemporary neoliberal or corporate 
food regime is characterized by the relative weakness of national states in a global system dominated by transnational corporations (McMichael 2009). This current context has inspired researchers to analyze transnational agrarian movements (Borras, Edelman and Kay 2008) and movements of global scope that challenge neoliberal hegemony, such as Via Campesina (Desmarais 2007). Scholars in this tradition have also considered the articulation between global processes and the mobilization of peasants and indigenous peoples at national and local scales (Edelman 1999; Otero 2004) and the re-embeddedness of farming systems with local markets and agro-ecosystems (Friedmann and McNair 2008). Food regime scholars, in short, converge in seeing social movements and contentious mobilization as a tool of subordinated actors to challenge neoliberalism. Accordingly, research has overwhelmingly emphasized resistance to agricultural biotechnology (Fitting 2011; Heller 2013; Klepek 2012; Newell 2008; Pechlaner 2012; Schurman and Munro 2010; Scoones 2008).

In this article, I argue that we can expand this scholarship by showing how powerful actors also use contentious mobilization to legitimize the contemporary neoliberal food regime, both in terms of its principles and institutions ("free market" policies) and its agrarian manifestations (agricultural biotechnology). To do so, I focus on the demobilization of popular social movements and the emulation of disruptive tactics by powerful agribusiness actors. In other words, rather than limiting my analysis to the mobilization of subordinated actors, I examine the demobilization of popular social movements, business mobilization, and the connections between the two (Lapegna 2014; Peine 2010; Peschard 2012; Roy 2013).

Below I bridge the literatures on critical agrarian studies, social movements, and "postneoliberalism" by way of example, inspecting the role of threats in unifying and spurring business mobilization (Walker and Rea 2014). I show that, in a context of anti-neoliberal policies, the taxation of soybean exports provided the incentives to unify agribusiness in Argentina. On the one hand, this agribusiness mobilization created political opportunities for candidates aligned with agribusiness interests and, on the other, it cemented certain alliances between the national government, authoritarian governors, and social movements. This shows that contentious politics can have an impact on institutional politics-a scenario less explored than the inverse one, i.e. the opportunities offered by institutional politics for the mobilization of challengers outside the polity. Finally, I show how the Argentine government challenges some neoliberal principles, while also favoring transnational corporations that dominate the contemporary neoliberal food regime. The net effect has been a deepening of the agrarian economic arrangements initiated in the neoliberal period.

\section{The State, Contentious Politics, and the Agrarian Boom in Argentina}

Argentina went from being a "poster child" of neoliberalism in the 1990 s to becoming one of the post-neoliberal countries of South America in the early $2000 \mathrm{~s}$. In the $1990 \mathrm{~s}$, the national government promoted a wide program of neoliberalization, closely following the recommendations of the International Monetary Fund (IMF). This process dismantled the institutional arrangements that governed agricultural production for much of the twentieth century, eliminating subsidies and regulatory bodies. By the mid-1990s, these institutional reforms paved the way for an agricultural boom in Argentina. In 1996, the national secretary of agriculture approved the use of genetically modified (GM) soybean seeds, engineered to endure a particular herbicide. Favored by "free market" policies, global agribusiness corporations eagerly 
promoted GM seeds that were adopted by farmers and agribusinesses. By the mid-2000s, more than half of the arable land in Argentina was sowed with GM soybeans (see figure 1, below). Beyond agriculture, the national government pegged the Argentine peso to the U.S. dollar, privatized state-owned companies, eliminated tariffs for exports and imports, and promoted a pro-business climate.

These neoliberal policies resulted in a cycle of protest (Tarrow 2005), as contention diffused among different social actors (Farinetti 2002; Silva 2009; Villalon 2007). In 1993 and 1995, several provinces affected by budget cuts experienced puebladas, or massive riots (Auyero 2003). The deregulation of agricultural markets also spurred the creation of new peasant and indigenous social movements in Northern provinces and the southern Patagonia region, and some of the associations of medium and small farmers adopted confrontational discourses and actions (Domínguez 2009; Giarracca 2001).

A disruptive form of protest, roadblocks, took hold in this ascending cycle of contention. Initially organized in company towns affected by massive layoffs prompted by the privatization of the national oil company (Auyero 2003; Barbetta and Lapegna 2001), roadblocks or "piquetes" became the main form of action for popular social movements towards the end of the 1990s (Rossi 2013; Scribano 1999; Silva 2009). Despite their ideological and organizational differences (see Svampa and Pereyra 2003), the variegated piquetero movement became a key political actor that besieged the administration of then-President Fernando de la Rúa (1999-2001) (Epstein 2003). By the end of the 1990s, the organizations of the unemployed and their visible, disruptive, and characteristic form of action (i.e. roadblocks) put the negative consequences of neoliberalization on the public agenda. The state responded to these contentious challenges by repressing social movements, dismissing their protests, or providing piecemeal resources to quell contention (Lodola 2005). By the mid-2000s, this confrontational relationship between popular social movements and the state was replaced by a collaborative relationship.

\section{From Neoliberalization to "Post-Neoliberalism"}

In December of 2001, lootings spread throughout several Argentine cities in the midst of a deep economic crisis, emerging from a "grey zone of politics" made up of political machines, party brokers, and law enforcement (Auyero 2007). As a reaction to the lootings, President de la Rúa declared a state of siege, which only prompted residents of Buenos Aires to protest this authoritarian response. The next day, December 20, thousands took over the streets and the president resigned.

Néstor Kirchner was sworn in as President in May of 2003, and he soon sought to differentiate his administration from the neoliberal policies of the 1990s. During his presidential campaign, Kirchner was not a well-known public figure and did not have a widespread support from his party (the Peronist or Justicialista party). Upon taking power, Kirchner sought to shake off the influence of Peronism's strongman Eduardo Duhalde, who had served as interim President in 2002. To do so, the Kirchner administration crafted an ideological position distinct from previous governments, while building alliances with organizations of the unemployed (piqueteros), which controlled nearly 208 thousand workfare subsidies in 2001 and more than 2.3 million in 2003 (Ronconi and Franceschelli 2007: 233).

Kirchner's approach to disruptive protests and piquetero organizations contrasted with that of his predecessors: his administration tolerated roadblocks, met with piquetero leaders, and established a relationship of collaboration and mutual support (Wolff 2007). The anti-neoliberal 
position of the new government resonated with many popular social movements. Yet social movement activists remained aware of the pragmatic aspect of Kirchner's alliances. As Julio, a local leader of a peasant movement told me in 2011: "To me, it was a strategy of Kirchner...The guy had no backbone; he needed support from somewhere. And he took the easy road; he won over the people and the organizations, that's why he emerged. Who knew of Kirchner back then? Nobody. So he found support in the organizations, and that worked for him."

The Kirchner administration developed what social movement scholars call a relationship of consultation (Giugni and Passy 1998: 86). The discursive and political affinities between the administration and popular social movements translated into forms of institutional collaboration, as the latter gained access to resources and joined the state bureaucracy. Access to the administration allowed social movement organizations to place their members in the offices and programs in charge of the issues that gave rise to the movements in the first place. As Luis D'Elía (the head of the national organization FTV, the largest piquetero organization) put it: "For us [the participation in the administration] allowed us to gather information, to get to know the territories, to be in touch with grassroots organizations; it's a capital that is useful for us" (quoted in Gómez and Massetti 2009: 43). In other words, from the point of view of national leadership, participation in the government gave organizations a national platform to expand their scope.

From the point of view of local activists, the collaboration with the government afforded material and political benefits. The FTV, for instance, developed a close relationship with the national Ministry of Social Development, which allowed them to appoint employees in provinces were the Ministry runs programs. This was the case for Estela, a peasant activist in Formosa, a province in northeast Argentina. Through the FTV, she and other eleven activists in a peasant movement were appointed as "Territorial Promoters for Social Change" (Promotores Territoriales para el Cambio Social), and they donated forty percent of their wages to fund the movement's activities. These appointments not only provided job security, but also a certain level of autonomy vis-à-vis the provincial government, which sees this peasant movement as part of the political opposition. In this and similar provinces ruled by authoritarian regimes, being an activist means to be unemployable in state agencies or programs. As a relative said to Estela when she tried to recruit him to the movement: 'I'm more than forty years old and I'm unemployed... I'm not going to oppose Gildo [the governor], are you nuts?"

Hugo is another case in point. He belongs to the same peasant movement as Estela, and in 2008 he was appointed to work in a national office in Buenos Aires on land tenure issues. In 2011 we met in Buenos Aires, near the train station where he starts his two-hour commute to the irregular settlement (asentamiento) where he lives. "The government gives things to the organizations, but does not always give what the organizations want; they 'bring down' dough [cash], but they do it badly (bajan guita pero la bajan mal)," he told me with a hint of despair. Despite this critical stance, Hugo is aware of the importance of being part of the "downward movement" of information and resources coming from the national state. His position provides his organization with vital information to keep track of the institutional and political realignments within the national government, and access to national allies can provide resources and access to state programs (more on this below).

Popular social movements and the Kirchner administration thus developed a relationship of mutual support. The mobilization of popular social movements buttressed specific government policies and offered Kirchner's administration political support at critical moments. For instance, in March 2005 when Kirchner confronted the oil company Shell over a spike in gas prices, 


\section{Journal of World-Systems Research}

several piquetero organizations supported a boycott, blocked gas stations, and protested at the company's offices. ${ }^{1}$ In November 2005 , the government-movement alliance took a transnational turn when massive demonstrations (many of them organized by piquetero organizations) derailed the project of United States, Canada, and Mexico to launch a Free Trade Agreement of the Americas (FTTA) during a summit in the Argentine city of Mar del Plata. A group of presidents, led by Hugo Chávez, Néstor Kirchner, and Lula da Silva, created a "counter bloc" that defeated the FTAA project and confirmed the power of movement-state alliances in Latin America, posing a challenge to the U.S. hegemony in the region (Smith 2014; Smith and Wiest 2012).

In Argentina and Latin America, then, the political stances and economic policies of Kirchner's government represented a break with the neoliberal past, in part achieved through the support of popular social movements. At the national scale, however, the affinities and collaborations between the post-neoliberal state and popular social movements also translated into a progressive demobilization of the latter. For instance, the data I gathered about contentious collective actions shows that the unemployed accounted for more than half of the protest events in 2003 , but by 2006 they only organized less than 10 percent of them (see Table 1).

Table 1. Contentious Collective Action by Actor, 2003-2006

\begin{tabular}{l|cc|cc|cc|cc|} 
& \multicolumn{8}{|c|}{ Contentious Collective Action } \\
\cline { 2 - 9 } & \multicolumn{2}{|c|}{$\mathbf{2 0 0 3}$} & \multicolumn{2}{|c|}{$\mathbf{2 0 0 4}$} & \multicolumn{2}{|c|}{$\mathbf{2 0 0 5}$} & \multicolumn{2}{c|}{$\mathbf{2 0 0 6}$} \\
\cline { 2 - 9 } Actor & $\mathbf{N}$ & $\mathbf{9}$ & $\mathbf{N}$ & $\mathbf{\%}$ & $\mathbf{N}$ & $\mathbf{\%}$ & $\mathbf{N}$ & $\mathbf{\%}$ \\
Unemployed/"Picketers" & 74 & 52.5 & 114 & 43.5 & 74 & 25.8 & 22 & 9.6 \\
Neighbors & 14 & 9.9 & 19 & 7.3 & 12 & 4.2 & 55 & 24.0 \\
Victims' Relatives \& & & & & & & & & \\
Friends & 9 & 6.4 & 21 & 8.0 & 25 & 8.7 & 15 & 6.6 \\
Public Sector Workers & 12 & 8.5 & 26 & 9.9 & 75 & 26.1 & 38 & 16.6 \\
Private Sector Workers & 7 & 5.0 & 23 & 8.8 & 21 & 7.3 & 18 & 7.9 \\
Transportation Workers & 7 & 5.0 & 15 & 5.7 & 42 & 14.6 & 20 & 8.7 \\
Other & 18 & 12.8 & 44 & 16.8 & 38 & 13.2 & 61 & 26.6 \\
\hline TOTAL & 141 & 100 & 262 & 100 & 287 & 100 & 229 & 100
\end{tabular}

Source: Database of Protests in Argentina. N $=919$

The macroeconomic policies of the Kirchner administration contrasted with the neoliberal policies of the $1990 \mathrm{~s}$, as his government eliminated most "free trade" arrangements and strengthened the state intervention in the economy. This was most clearly evidenced in the taxes applied to agricultural exports. In 2002, the interim government of Duhalde reinstated the export taxes ("retenciones") that had been eliminated in the $1990 \mathrm{~s}$. Starting in 2002 at a rate of 10 percent, retenciones were increased later that year to 20 percent. During Kirchner's presidency, export taxes for soybeans were raised to 35 percent and the administration used this revenue to

\footnotetext{
1 "Kirchner llamó a un 'boicot nacional' por los aumentos" La Nación, March 102005 and "Escracharon a Shell y bloquearon dos estaciones," Página 12, March 11, 2005.
} 
fund what some call an "export-oriented populism" (Richardson 2009). ${ }^{2}$ These polices, however, did not deter agricultural expansion. On the contrary, the acreage and production of GM soybeans increased every year, as Figures 1 and 2 illustrate. By the end of Néstor Kirchner's government, the exports of the soybean agro-industrial complex (soybeans, oil, and soybean meal) represented nearly one-fourth of the total Argentine exports (INDEC 2012).

Figure 1. Soybean Area in Argentina, 1988-2013 (in hectares)

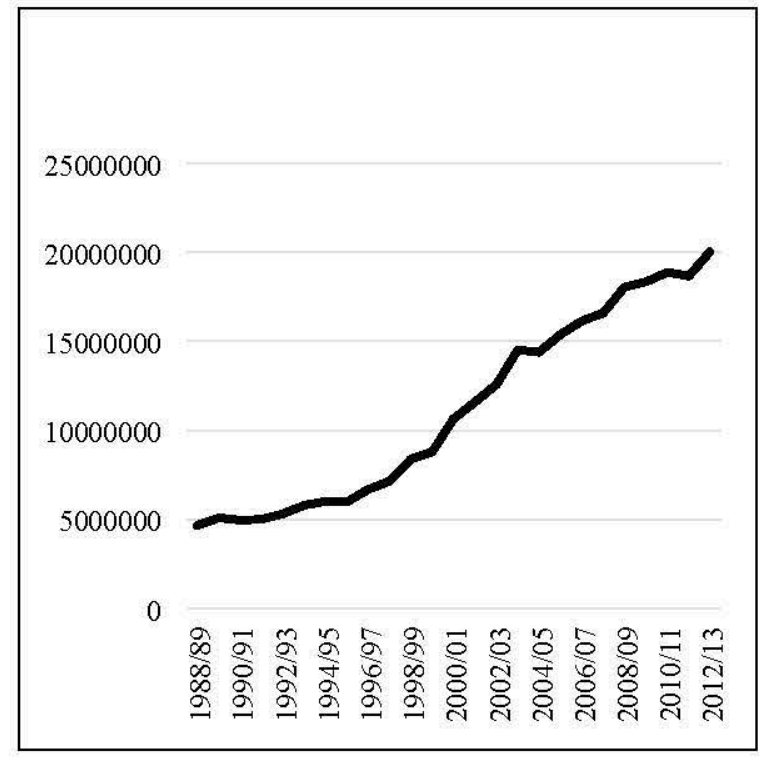

Source: Ministerio de Agricultura, Ganadería y Pesca

These post-neoliberal changes should not obscure key continuities with previous periods, particularly regarding agricultural production and subnational politics. The expansion of agribusiness and GM soybean production resulted in a series of negative consequences for rural populations and the environment. First, the growing demand for soybeans at the global level increased pressures for arable land in the Argentine countryside. In northern provinces, large tracts of land held by provincial elites increasingly encroached on the small properties of peasant families and indigenous communities. This demand for land and processes of accumulation by dispossession soon resulted in violent conflicts (Cáceres 2014). Since 2011, the murder of peasant activists in northern Argentina have occurred in the provinces of Santiago del Estero, Tucumán, and Formosa (Lapegna 2013a), while leaders and members of peasant-indigenous movements are constantly harassed (Domínguez and De Estrada 2013).

Second, the diffusion of GM soybean production has increased processes of deforestation (Pengue 2005). According to governmental reports, between 1998 and 2008 almost 1.7 million acres of native forest were destroyed (Leguizamón 2014). Third, the extensive production of

\footnotetext{
2 "Export taxes comprised 8 to $11 \%$ of the Kirchner government's total tax receipts, and around two-thirds of thisnearly US\$2 billion in 2006 - came from soy exports" (Richardson 2009: 242).
} 
GM, herbicide-resistant soybeans have resulted in agrochemical runoff into water supplies and herbicide drifts contaminating the air, putting the health of rural and suburban populations at risk (Binimelis, Pengue and Monterroso 2009).

Figure 2. Soybean Production in Argentina, 1988-2013 (in metric tons)



Source: Ministerio de Agricultura, Ganadería y Pesca

In short, the reliance of the post-neoliberal state on primary exports shows strong continuities with the neoliberal period. This, in turn, creates a cycle in which agriculture "generates resources to the government (..), a portion of which is redistributed through social policies, which increases well-being, which provides the social and political support needed to validate the model" (Cáceres 2014: 24-25). Politically, this socio-economic and environmental scenario translates in partnerships between national and subnational governments. Governors and provincial elites profit from primary economic activities and, in turn, support the national government. These trends, as we will see next, deepened during the administrations of Néstor Kirchner's successor and wife, Cristina Fernández de Kirchner.

\section{Agribusiness Mobilization and Die-Hard Neoliberalism}

In October 2007, Cristina Fernández de Kirchner (a Peronist Senator and hereafter CFK) was elected president in a landslide, obtaining more than 45 percent of the votes. In December of 2007 , she was sworn in and shortly after entered into a profound conflict with agribusiness. In March 2008, the national government raised export taxes from 35 to 44 percent, triggering the opposition of medium and large landowners and farmer's associations. Supported by media conglomerates and national newspapers, these farmers launched a lockout, refusing to bring 
crops and meat to the market, blocking roads throughout Argentina between March and July. As a counter-reaction to the contentious collective actions of agribusiness and middle classes, popular social movements mobilized in Buenos Aires in support of the national government in March and April of 2008.

Farmer's associations had organized shorter protests against export taxes in previous years. But in 2008 they were able to build a broad coalition in order to create a sustained challenge to the government. Massive demonstrations in the city of Rosario further emboldened agribusiness, which took the offensive and demanded the complete elimination of all export taxes (Giarracca and Teubal 2010). Agribusinesses, farmers, and sectors of the middle classes thus adopted the form of action (the roadblock) that was generally used by poor people's movements and organizations of the unemployed. An analysis of protest events between 2003 and 2006 shows that the use of roadblocks as a tactic was progressively decoupled from unemployed workers and adopted by "neighbors" (vecinos), a category that journalists often use in reference to middle class demonstrators. As Figure 3 illustrates, whereas piqueteros organized more than $60 \%$ of the roadblocks in $2003-2004$, they only organized $10 \%$ of the roadblocks by 2006 . In contrast, while vecinos only accounted for $10 \%$ of the roadblocks in 2003 , the number had risen to $50 \%$ by 2006.

Figure 3. Blockade by Participant, 2003-2006

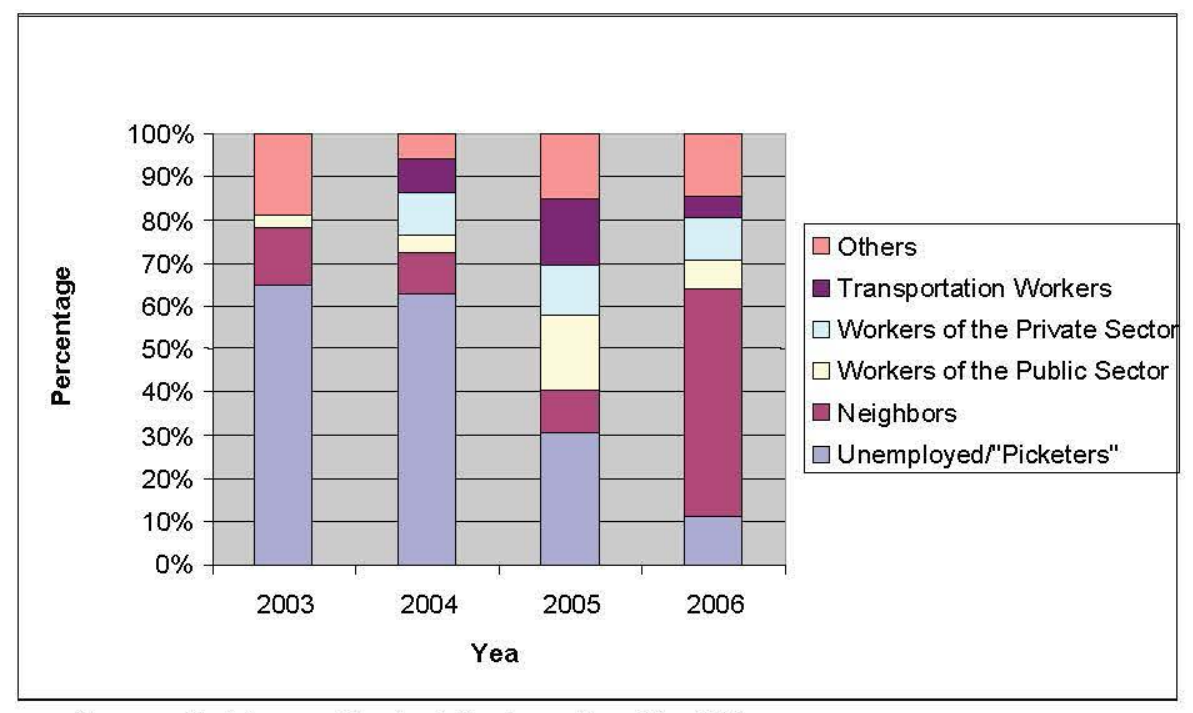

Source: Database of Protests in Argentina. $N=919$

The trend evidenced by my catalog of protest events, together with the agribusiness mobilization of 2008, suggests a process of tactical emulation. As piquetero organizations and popular social movements progressively abandoned disruptive contention and collaborated with the government (moving, so to speak, from the streets to the offices), agribusiness emulated the disruptive tactic of roadblocking, moving from the farms to the roads. Whereas the streets, roads, and squares were the turf of popular social movements during the $1990 \mathrm{~s}$, by 2008 these spaces had been occupied by the mobilized middle and upper classes in support of "free market" policies. 
Agrarian Boom in Post-Neoliberal Argentina 79

incorporated pro-agribusiness activists as candidates, electing thirteen of them to the lower house and one to the Senate.

As I explain in the next section, the national government responded to the agrarian challenge in two ways. First, it created new institutional spaces catering to organizations and activist networks closely connected to the government. Second, it expressed support for global agribusiness corporations, creating dilemmas and ambiguities that puzzled many of the social movements supporting the government.

\section{Social Movement Dilemmas and the Ambiguities of the Post-Neoliberal State}

After the confrontation with agribusiness, the national government created institutional spaces to garner the support of small farmers and peasants. In 2009, the government converted the Social Agricultural Program (PSA), a program created in the 1990s and renewed annually, into a permanent office: the Sub-Secretaria de Desarrollo Rural y Agricultura Familiar (SSDRAF, Under-Secretary of Rural Development and Family Agriculture). This institutional recognition was well received by peasant social movements, but they also had to face a complex and sometimes contradictory scenario. On one hand, peasant movements supported a national government that recognized them as a valid social and political actor, gave them access to institutional spaces, and reversed some of the neoliberal policies of the 1990s. On the other hand, their constituency had been suffering the consequences of the sweeping expansion of transgenic agriculture, which the government did little to address. The conflict between agribusiness and the national government was manifested in a clash between the neoliberal views of the former and the post-neoliberal policies of the latter. Yet the conflict was mostly about who had the right to reap the benefits of soybean exports, while the socio-environmental consequences of GM soybean expansion were largely ignored.

During CFK's second term in office (2011-2015), the relationship between the national government and popular social movements was redefined by the government's stance towards transgenic agriculture, which further exposed the ambiguities of its "post-neoliberalism." In the 2011 elections, CFK built her political support on three pillars: the Peronist party, provincial governors, and social movements created after 2003. On the heels of the conflict between the government and agribusiness, the CFK administration cemented its relationship with governors and the Peronist party to maintain political stability and ensure support in Congress. The alliance of the national government with governors put social movements in a difficult position, since provincial elites are often business partners with soybean growers and authoritarian governors who usually dismiss or repress peasant movements (Domínguez 2009).

Since 2011 the CFK administration has sidelined social movements created in the 1990 s (that is, those movements predating the start of Néstor Kirchner's regime) and relied instead on the social movement organizations that emerged during the Kirchner period. These social movement organizations doubled as political cliques of the Peronist party and factions of the national government. In 2012, the government launched an umbrella network (Unidos y Organizados, "United and Organized") that included, among others, the group "La Cámpora" led by Máximo Kirchner (the son of Néstor and Cristina Kirchner), "Kolina," a faction of the national government led by Alicia Kirchner (the sister of Néstor Kirchner and minister for social development), and the "Movimiento Evita" led by Emilio Pérsico (more on him below).

Members of local organizations predating the Kirchner regime were sidelined by these 
realignments, but they also felt that it was hard to disengage from their connections to the government, lest be isolated, lose their voice, or be left without resources to organize activities and address the needs of their members.

I witnessed these dilemmas firsthand in 2009 while participating in a meeting at the office of a peasant social movement in a small town in northeast Argentina. At the meeting, Hugo (a leader appointed to a program in Buenos Aires introduced above) argued for further involvement with the FTV. He informed movement participants about a recently created CMP, "Central de Movimientos Populares," an initiative of FTV to create a confederation of popular organizations and social movements.

Hugo - If we were to analyze what the FTV offered and what we offered, I think it's about the same. (...) CMP has a political goal, if we're not interested in participating in electoral politics, then we're not going to rise up or grow. The CMP is targeting the 2011 elections, but if we want to get things through CMP we have to commit. I talked to [an official of the under-secretary of rural development] and he told me that they want to support CMP. He underlined that they will do that with "compañero organizations;" in other words, Peronist organizations. We have to see if it's convenient for us, if we want that. CMP isn't going to have resources, but could give contacts (...) If we want to get in on this, the time is now. Later, you're not going to get in at the end of the line.

Arturo - We have to think seriously about what it would mean to create CMP here, to see with which organizations [are we going to work with].

Julio - If we think about the elections, we have to be the initiators. If not, later we join the others and it won't work. You have to get on the line and be at the will of others [tenés que ponerte en la cola, y depender de otro]

Hugo - If we enter CMP, it's now. CMP is FTV. If someone from here gets ahead of us, we're screwed; there will be fewer resources. To achieve this, we have to say to Luis [the head of FTV], 'reserve us the first place.'

When I met with Hugo in 2012 , he said that during the 2008 conflict with agribusiness, his peasant movement supported the government, but that involvement had them "bouncing from place to place" ("estuvimos de acá para allá"). They mobilized in Buenos Aires and neglected the inner workings of the movement ("descuidamos lo de adentro"). "We tried to be in every place to make sure we didn't miss anything, and we [end up] missing ourselves," he told me metaphorically ("Tratamos de cubrir todos los espacios para no quedarnos afuera, y quedamos afuera de nosotros mismos"). When I saw him again in 2013, he summarized the relationship between social movements and the government, saying: "What happened with the Kirchner government was that they took our claims and made them theirs, and in doing so, they neutralized us." During our conversation I mentioned that Emilio Pérsico (the leader of the "Movimiento Evita") had been appointed under-secretary of Rural Development and Family Agriculture. He was a public official in the province of Buenos Aires in 2005, and his appointment puzzled peasant social movements given his relative lack of experience with rural and peasants" issues. "We made demands for small farmers and peasants, but now, who is in 
charge? A neighborhood leader [referring to Pérsico]. They leave you without arguments. They always seem to think that we have put out our hands to see what they give us [like a beggar]. And anyone seems to be better than us when it comes to filling the positions." This was how Hugo expressed his feelings of peasant movements being sidelined. In 2011, Estela also voiced her discontent with her work at the Ministry of Social Development: "If you criticize something, they tell you that you belong to the opposition." She was also dissatisfied with the pressures she received to do political work for "Kolina," a faction within the government led by Minister Alicia Kirchner.

Specific policies of the national Ministry of Agriculture and discourses of CFK contributed to tense relationships between peasant-indigenous social movements and the national government, while also revealing the ambiguities of the post-neoliberal state in Argentina. During its second term, CFK's administration maintained a cold stance towards Argentine agribusiness, yet its relationships with global agribusiness corporations progressively improved. In 2012, for instance, CFK expressed her support for Monsanto, praising the company for opening a plant to produce GM corn seeds. In June 2012, President CFK stated:

I was with Monsanto, which announced to us a very important investment concerning corn. (...) And besides they were very happy because Argentina today is - shall we say - at the forefront in matters of biotechnological progress (...) Here I have - and the truth is that I want to show you it all because I am very proud - the prospectus of Monsanto [which made] a very important investment in producing a new transgenic corn seed in the province of Córdoba. (...) And today, the head [of Monsanto] told me that they were very impressed by the support that our government was giving to science and technology. You should all be certain that we are going to continue in the same line. (..) We are nearly 40 million residents [in Argentina] and we have a territory that is the eighth [largest] in the world. This places us in a 'pole position' [sic] in terms of food producers and biotechnology in Argentina.

In this speech, CFK also referenced the "Strategic Agro-Food Plan, 2020," an initiative launched in September 2011 to increase agricultural production and further expand the area of cultivated land in Argentina. She finally referred to the acceptance of GM seeds, reflecting the rate of government approval for new GM seeds. During her first two terms in office (20082013), eighteen new GM crops were released in Argentina (in contrast to the eleven approved in the decade before, see Figure 5).

In 2012 shortly after CFK praised Monsanto, the Minister of Agriculture announced the approval of a new variety of GM soy, which combines resistance to both the Roundup herbicide and pests. During an event organized by Monsanto at a five-star hotel, the Minister said: "I fundamentally agree with Monsanto, not only in the approval of the 'Intacta RR2' [the new GM soybean], but also in the investment and trust that it has given Argentina through investments that have already been announced by our nation's president."3 The government continued this support by promoting policies that advance global agribusiness interests and ensuring a friendly business environment. For example, the government presented a bill in Congress to limit seed use and strengthened intellectual property rights over GM seeds. ${ }^{4}$ It also dropped a long-running

\footnotetext{
3 "Una de cal y muchas de arena: Monsanto en Argentina" Marcha, August 24 2012.

4 "Semillas en debate", Página 12, October 5, 2012.
} 
investigation into tax evasion by Cargill, one of the largest global corporations in the soybean export market (Teubal, Domínguez and Sabatino 2005) (Kneen 2002). ${ }^{5}$

Figure 5. GM Seeds Approved for Commercialization in Argentina, 1996-2013

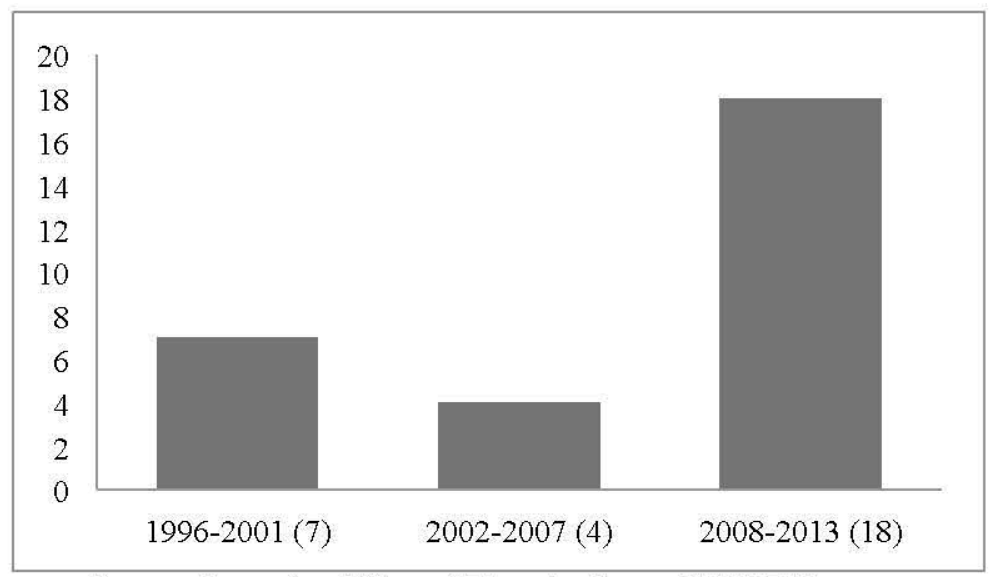

Source: Argentine Office of Biotechnology, CONABIA

\section{Conclusion}

In this article, I provided an overview of recent Argentine history to expand the purview and to bridge social movement research and critical agrarian studies, and illuminate some of the contradictions and ambiguities of the contemporary post-neoliberal scenario in Latin America. During the 1990s, Argentine popular social movements opened political opportunities for political actors that shared with them a similar anti-neoliberal position. The challenge to neoliberalism in Latin America thus emerged from key charismatic figures but also, and perhaps fundamentally, from the sustained efforts of popular social movements. The collaboration and consultation between governments and social movements, however, resulted in the progressive replacement of disruptive contention with more conventional forms of mobilization. In the context of post-neoliberal governments, social movement organizations became increasingly ensnared in state bureaucracy and patronage politics (Lapegna 2013b; Wolff 2007: 22-24). It would be simplistic, however, to interpret the institutional incorporation of popular social movements as a sign that they are duped or directly controlled by the national government. Social movement leaders are keenly aware of the challenges and perils entailed in supporting the national government. At the same time, it is hard for leaders to reject the access to resources offered by the national government, knowing that the members of their movement have urgent material needs.

Paradoxically, the mobilization of subordinate actors against processes of neoliberalization in the 1990 s also opened opportunities for pro-neoliberal social actors. The wave of popular protest in the 1990s legitimized the use of roadblocks as a form of protest. As popular social movements progressively refrained from disruptive mobilizations (i.e. roadblocks), powerful social actors emulated this form of action to protest the curbing of "free markets" via export taxes and the

\footnotetext{
5 "Giro de la AFIP: desistió de un reclamo millonario contra Cargill" La Nación, October 3, 2013.
} 
threat posed by the post-neoliberal state. In 2008, the actors of agribusiness appropriated roadblocks as a form of disruptive mobilization to promote their interests, oppose the postneoliberal agenda of the national government, and ultimately gain institutional spaces in Congress.

The Argentine case illustrates that so-called post-neoliberal governments have given short shrift to the socio-environmental effects of commodity booms (Altieri and Pengue 2006; Bebbington 2012; Haarstadt 2012). In Argentina, the macro-economic policies of the postneoliberal state have had a Keynesian orientation in that they seek to stimulate aggregate demand by increasing government spending and the income of popular sectors. A large part of revenues redistributed by the state, however, were created by the production of GM soybeans that have had negative socio-environmental consequences for some of those very same sectors; namely, peasant families, indigenous communities, and rural populations. The government of CFK first confronted Argentine agribusiness, and then supported global agribusiness corporations during the second term, suggesting the power of what Peter Newell (2009) calls "bio-hegemony."

In terms of delineating a research agenda, agribusiness mobilization in Argentina suggests the importance of paying closer attention to two social processes: the dynamics of mobilization and demobilization connecting subordinate and powerful actors with institutional politics, and the protean possibilities of neoliberalism. First, by further investigating the iterative relationships between institutional and contentious politics we can go beyond the customary emphasis on how the former informs the latter and better capture the ways in which contention modifies elite alliances and the trajectory of governments and states.

Second, neoliberalization needs not to be imagined in solely negative terms. The neoliberal polices of the 1990s in Argentina not only implied budget cuts, privatization, and the adoption of export-oriented transgenic agriculture, but also promoted the creation of political subjectivities aligned with these ideas and policies. This means that we need to identify the productive effects of neoliberalization and understand it as a process that not only destroyed the social fabric, but also benefitted certain social actors (e.g. medium to large agribusiness in Argentina, see Gras 2009) and constructed a political common sense that motivated the massive agribusiness mobilization in 2008. Business mobilization tends to be more effective when their collective actions look like grassroots campaigns (Walker and Rea 2014). Argentine agribusinesses' capacity to mobilize in large numbers should prompt us to pay closer attention to how a "neoliberal reason" is constructed by think tanks and foundations (Peck 2010), but also to identify the ways in which neoliberal ideas, policies, and values are transmitted and adopted by a variety of actors beyond the business community.

Agricultural biotechnology is one of the main tools of the current global food regime controlled by corporations and governed by neoliberal principles. Together with the United States and Brazil, Argentina is one of the leading players in the global production of genetically modified crops, a key input in today's feed and food industry. As a battleground in the contemporary global food regime, Argentina is likely to play an important role in the future agricultural production at a global scale. Thus, the interplay between popular social movements, business mobilization, and the state analyzed here, although national in scale, could thus have global reverberations. 


\section{References}

Altieri, Miguel A., and Walter Pengue. 2006. "GM soybean: Latin America's new colonizer." Pp. 13-17 in Seedling.

Auyero, Javier. 2003. Contentious lives: Two Argentine Women, Two Protests, and the Quest for Recognition. Durham: Duke University Press. . 2007. Routine Politics and Violence in Argentina: The Gray Zone of State Power. New York: Cambridge University Press.

Barbetta, Pablo, and Pablo Lapegna. 2001. "Cuando la protesta toma forma: los cortes de ruta en el norte salteño." Pp. 231-57 in La protesta Social en la Argentina. Transformaciones económicas y crisis social en el interior del pais, edited by Norma Giarraca. Madrid, Buenos Aires: Alianza Editorial.

Bebbington, Anthony (Ed.). 2012. Social Conflict, Economic Development and the Extractive Industry: Evidence from South America. London and New York: Routledge.

Binimelis, Rosa, Walter Pengue, and Iliana Monterroso. 2009. '"Transgenic treadmill': Responses to the emergence and spread of glyphosate-resistant johnsongrass in Argentina." Geoforum 40(4):623-33.

Borras, S.M., M. Edelman, and C. Kay. 2008. Transnational agrarian movements confronting globalization: Wiley Online Library.

Cáceres, Daniel M. 2014. "Accumulation by Dispossession and Socio-Environmental Conflicts Caused by the Expansion of Agribusiness in Argentina." Journal of Agrarian Change 15(1):116-47.

Cameron, Maxwell A, and Eric Hershberg. 2010. Latin America's Left Turns: Politics, Policies, and Trajectories of Change. Boulder, Colorado: Lynne Rienner Publishers

Desmarais, Annette Aurélie. 2007. La Via Campesina: globalization and the power of peasants. Halifax: Fernwood Pub.

Domínguez, Diego. 2009. "La lucha por la tierra en Argentina en los albores del Siglo XXI. La recreación del campesinado y de los pueblos originarios." in Facultad de Ciencias Sociales. Buenos Aires: Universidad de Buenos Aires.

Domínguez, Diego Ignacio, and María De Estrada. 2013. "Asesinatos y Muertes de Campesinos en la Actualidad Argentina: La Violencia como Vector (Des)Territorializador." Astrolabio 10:489-529.

Domínguez, Francisco. 2011. "Venezuela's opposition: desperately seeking to overthrow Chavez." Pp. 113-29 in Right-wing politics in the new Latin America : reaction and revolt, edited by Francisco Domínguez, Geraldine Lievesley, and Steve Ludlam. London: Zed Books.

Eaton, Kent. 2007. "Backlash in Bolivia: Regional autonomy as a reaction against indigenous mobilization." Politics \& Society 35(1):71-102.

Edelman, Marc. 1999. Peasants Against Globalization: Rural Social Movements in Costa Rica. Stanford, California: Stanford University Press.

Epstein, Edward. 2003. "The piquetero movement of Greater Buenos Aires: working class protest during the current Argentine crisis." Canadian Journal of Latin American and Caribbean Studies 28(55-56):11-36.

Fairfield, Tasha. 2011. "Business power and protest: Argentina's agricultural producers protest in comparative context." Studies in comparative international development 46(4):424-53. 
Farinetti, M. 2002. "La conflictividad social después del movimiento obrero." Nueva Sociedad 182:61-75.

Fitting, Elizabeth. 2011. The Struggle for Maize: Campesinos, Workers, and Transgenic Corn in the Mexican Countryside. Durham and London: Duke University Press.

Friedmann, Harriet. 2005. "From colonialism to green capitalism: Social movements and emergence of food regimes." Research in Rural Sociology and Development 11:227-64.

Friedmann, Harriet, and Amber McNair. 2008. "Whose Rules Rule? Contested Projects to Certify 'Local Production for Distant Consumers'." Journal of Agrarian Change 8(2$3): 408-34$.

Giarracca, Norma (Ed.). 2001. La Protesta Social en la Argentina: Transformaciones Económicas y Crisis Social en el Interior del País. Buenos Aires: Alianza.

Giarracca, Norma, and Miguel Teubal (Eds.). 2010. Del paro agrario a las elecciones de 2009: tramas, reflexiones y debates. Buenos Aires: Antropofagia.

Giugni, Marco G., and Florence Passy. 1998. "Contentious politics in complex societies." Pp. 81108 in From contention to democracy, edited by Marco Giugni, Doug McAdam, and Charles Tilly. Lanham, MD: Rowman \& Littlefield.

Gómez, Marcelo, and Astor Massetti. 2009. Los movimientos sociales dicen: conversaciones con dirigentes piqueteros. Buenos Aires: Nueva Trilce.

Gras, Carla. 2009. "Changing Patterns in Family Farming: The Case of the Pampa Region, Argentina." Journal of Agrarian Change 9(3):345-64.

Haarstad, Håvard (Ed.). 2012. New Political Spaces in Latin American Natural Resource Governance. New York: Palgrave Macmillan.

Heller, Chaia. 2013. Food, Farms, and Solidarity: French Farmers Challenge Industrial Agriculture and Genetically Modified Crops. Durham and London: Duke University Press.

INDEC. 2012. "Exportaciones del complejo soja, por zonas económicas, según componentes. Años 2006-2010.". Buenos Aires: Instituto Nacional de Estadísticas y Censos (INDEC).

Klepek, James. 2012. "Against the grain: knowledge alliances and resistance to agricultural biotechnology in Guatemala." Canadian Journal of Development Studies/Revue canadienne d'études du développement 33(3):310-25.

Kneen, Brewster. 2002. The invisible giant. Cargill and its transnational strategies. London: Pluto Press.

Lapegna, Pablo. 2013a. "The Expansion of Transgenic Soybeans and the Killing of Indigenous Peasants in Argentina." Societies without Borders: Human Rights and the Social Sciences $8(2): 291-308$.

2013b. "Social Movements and Patronage Politics: Processes of Demobilization and Dual Pressure." Sociological Forum 28(4):842-63.

. 2014. "Global Ethnography and Genetically Modified Crops in Argentina: On

Adoptions, Resistances, and Adaptations." Journal of Contemporary Ethnography 43(2):202-27.

Leguizamón, Amalia. 2014. "Modifying Argentina: GM soy and socio-environmental change." Geoforum 53:149-60.

Levitsky, Steven, and Kenneth M Roberts (Eds.). 2011. The Resurgence of the Latin American Left. Baltimore: John Hopkins University Press.

Lodola, Germán. 2005. "Protesta popular y redes clientelares en la Argentina: El reparto federal del Plan Trabajar (1996-2001)." Desarrollo económico 44(176):515-36. 
McMichael, Philip. 2009. "A food regime genealogy." The Journal of Peasant Studies 36(1):139-69.

Newell, Peter. 2008. "Trade and Biotechnology in Latin America: Democratization, Contestation and the Politics of Mobilization." Journal of Agrarian Change 8(2-3):345-76. .2009. "Bio-Hegemony: The Political Economy of Agricultural Biotechnology in Argentina." Journal of Latin American Studies 41(1):27-57.

Otero, Gerardo. 2004. "Global economy, local politics: Indigenous struggles, civil society and democracy." Canadian journal of political science 37(2):325-46.

Pechlaner, Gabriela. 2012. Corporate Crops: Biotechnology, Agriculture, and the Struggle for Control. Austin, TX: University of Texas Press.

Peck, Jamie. 2010. Constructions of Neoliberal Reason. New York: Oxford Univ Pr.

Peine, Emilie Kaye. 2010. "Corporate Mobilization on the Soybean Frontier of Mato Grosso, Brazil." Pp. 132-49 in Contesting Development: Critical Struggles for Social Change, edited by Philip McMichael. New York: Routledge.

Pengue, Walter A. 2005. "Transgenic Crops in Argentina: The Ecological and Social Debt." Bulletin of Science Technology Society 25(4):314-22.

Peschard, Karine. 2012. "Unexpected discontent: exploring new developments in Brazil's transgenics controversy." Canadian Journal of Development Studies/Revue canadienne d'études du développement 33(3):326-37.

Petras, James F., and Henry Veltmeyer. 2005. Social movements and state power: Argentina, Brazil, Bolivia, and Ecuador. London: Pluto Press.

Richardson, Neal. 2009. "Export-Oriented Populism: Commodities and Coalitions in Argentina." Studies in Comparative International Development (SCID) 44(3):228-55.

Ronconi, L., and I. Franceschelli. 2007. "Clientelism, Public Workfare and the Emergence of the Piqueteros in Argentina." Pp. 228-52 in Political institutions and development: failed expectations and renewed hopes, edited by Natalia Dinello and Vladimir Popov. Northhampton, MA: Edward Elgar.

Rossi, Federico M. 2013. "Piqueteros (workers/unemployment movement in Argentina)." in The Wiley-Blackwell Encyclopedia of Social and Political Movements, edited by David A. Snow, Donatella della Porta, Bert Klandermans, and Doug McAdam. Malden, MA: Wiley-Blackwell.

Roy, Devparna. 2013. "To Bt or not to Bt? State, civil society, and firms debate transgenic seeds in democratic India." Pp. 153-69 in The Neoliberal Regime in the Agri-Food Sector, edited by Steven Wolf and Alessandro Bonanno. London: Routledge.

Schurman, Rachel, and William A. Munro. 2010. Fighting for the Future of Food: Activists Versus Agribusiness in the Struggle Over Biotechnology. Minneapolis: University of Minnesota Press.

Scoones, Ian. 2008. "Mobilizing Against GM Crops in India, South Africa and Brazil." Journal of Agrarian Change 8(2-3):315-44.

Scribano, Adrián. 1999. "Argentina 'cortada': cortes de ruta y visibilidad social en el contexto del ajuste." Pp. 45-71 in Lucha Popular, democracia, neoliberalismo: protesta popular en América Latina en los años del ajuste., edited by Margarita López Maya. Caracas: Nueva Sociedad.

Silva, Eduardo. 2009. Challenging Neoliberalism in Latin America. New York: Cambridge University Press. 
Smith, Jackie. 2014. "Counter-hegemonic networks and the transformation of global climate politics: rethinking movement-state relations." Global Discourse 4(2-3):120-38.

Smith, Jackie, and Dawn Wiest. 2012. Social movements in the world-system: The politics of crisis and transformation. New York: Russell Sage Foundation.

Svampa, Maristella, and Sebastián Pereyra. 2003. Entre la ruta y el barrio. La experiencia de las organizaciones piqueteras. Buenos Aires: Biblos.

Tarrow, Sidney. 2005. Power in Movement: Social Movements and Contentious Politics. New York: Cambridge University Press.

Teubal, Miguel, Diego Domínguez, and Pablo Sabatino. 2005. "Transformaciones agrarias en la Argentina. Agricultura industrial y sistema agroalimentario." Pp. 37-78 in El campo argentino en la encrucijada. Estrategias y resistencias sociales, ecos en la ciudad, edited by Norma Giarracca and Miguel Teubal. Buenos Aires: Alianza Editorial.

Villalon, Roberta. 2007. "Neoliberalism, Corruption, and Legacies of Contention: Argentina's Social Movements, 1993-2006." Latin American Perspectives 34(2):139-56.

Walker, Edward T., and Christopher M. Rea. 2014. "The Political Mobilization of Firms and Industries." Annual review of sociology 40:281-304.

Webber, Jeffery R. 2011. From rebellion to reform in Bolivia: Class struggle, indigenous liberation, and the politics of Evo Morales. Chicago: Haymarket Books.

Weyland, Kurt. 2010. "The performance of leftist governments in Latin America." Pp. 1-27 in Leftist Governments in Latin America, edited by Kurt Weyland, Raúl Madrid, and Wendy Hunter. New York: Cambridge University Press.

Wolff, Jonas. 2007. "(De-) Mobilising the Marginalised: A Comparison of the Argentine Piqueteros and Ecuador's Indigenous Movement." Journal of Latin American Studies 39(1):1-29. 